\title{
NEXUS BETWEEN FINANCIAL INNOVATION AND FINANCIAL INTERMEDIATION IN NIGERIA'S BANKING SECTOR
}

\section{Ejinkonye Remigius Chinwoke ${ }^{1}$ and Okonkwo Ikeotuonye Victor ${ }^{2}$}

\author{
${ }^{1}$ Ph.D student, Department of Banking and Finance, Nnamdi Azikiwe University, Awka, \\ Anambra State Nigeria. Lecturer, Department of Banking and Finance, College of \\ Management Sciences, Evangel University, Akaeze, Ebonyi State. E-mail: \\ rejinkonye@gmail.com (Phone: +2348039562388)
}

\begin{abstract}
${ }^{2}$ Professor of Financial and Risk Management, Department of Banking and Finance, Nnamdi Azikiwe University, Awka, Anambra State, Nigeria and of Insurance and Risk Management Department of Enugu State University of Science and Technology Enugu Nigeria. E-mail: vi.okonkwo@unizik.edu.ng (Phone: +2348064258055)
\end{abstract}

\author{
Cite this article: \\ Ejinkonye R.C., Okonkwo \\ I.V. (2021), Nexus Between \\ Financial Innovation and \\ Financial Intermediation in \\ Nigeria's Banking Sector. \\ African Journal of Accounting \\ and Financial Research 4(3), \\ 162-179. DOI: \\ 10.52589/AJAFR- \\ VN7JRC1Z.
}

\section{Manuscript History \\ Received: 11 Nov 2021 \\ Accepted: 29 Nov 2021 \\ Published: 13 Dec 2021}

Copyright () 2020 The Author(s). This is an Open Access article distributed under the terms of Creative Commons AttributionNonCommercial-NoDerivatives 4.0 International (CC BY-NC-ND 4.0 ), which permits anyone to share, use, reproduce and redistribute in any medium, provided the original author and source are credited.
ABSTRACT: This study evaluated the relationship between financial innovation and financial intermediation in Nigeria. It seems that banks in Nigeria may have a problem of deposit-loan mismatch and losing customers to start-ups given increasing cost of deposits attributable to disruptive practice arising from financial innovations. The specific objectives of this study were to examine the relationship between financial innovation (value of the automated teller machine, internet banking, mobile banking, point of sale transactions) and financial intermediation (commercial banks deposit mobilization) in Nigeria for the period 20092018. This study was anchored on the financial innovation theory of Joseph Schumpeter, which states that technology creates opportunities for new profits and super profits as a result of increased investment by banks or financial institutions on products of innovation. The ordinary least square was used to estimate the parameters. The data used were extracted from the Central Bank of Nigeria statistical bulletin. The results showed that there is a positive and significant relationship between financial innovation (value of Automated Teller Machine) and financial intermediation (commercial banks deposit mobilization) in Nigeria; there is a positive but no significant relationship between financial innovation (internet banking) and financial intermediation (commercial banks deposit mobilization) in Nigeria; there is a positive but no significant relationship between financial innovation (mobile banking) and financial intermediation (commercial banks deposit mobilization) in Nigeria; and there is no positive and significant relationship between financial innovation (point of sale transactions) and financial intermediation (commercial banks deposit mobilization) in Nigeria. The f-test result showed that financial innovations proxies jointly related significantly to commercial banks' deposits. The work concludes that financial innovations contributed to commercial banks' deposits in Nigeria. The researchers recommended among others that banks should improve on the security of transactions done on their platforms, continue to improve and partner with start-ups in technological infrastructure, improve on power and network stability, deploy more innovative products, and improve on the efficiency of bank staff by regular training.

KEYWORDS: Financial Innovation, Financial intermediation, Banks deposits, internet Banking and mobile banking. 


\section{INTRODUCTION}

In an economy, the mode of payments plays an essentially important role in the smooth functioning of all economic sectors including banking and finance as well as real estate. An efficient system of payment is one that provides instantaneous settlement of financial transactions and expedites the exchange of goods and services in a prompt, protected, and reliable manner. One way of improving the payment system is leveraging innovations, say financial innovations. Of course, financial innovations have extended global acceptance and provided new financial instruments, processes, services, institutions, and market segments, etc (Tahir, Shah, Arif, Ahmad, Aziz \& Ullah, 2018).

Blach (2011) maintains that the dominant feature of the modern financial system is the high pace of innovations, both in terms of their number and value. Innovations are implied when new ideas, solutions and instruments are implemented in order to change the conditions of a business entity and to improve its situation (Blach, 2011). The term, innovation, was used to describe the changes in the technological solutions, creating new combinations of productive means, generating the above average rates of return and thus enhancing the dynamic development of the overall economy (Targalski, as cited in Blach, 2011).

Financial innovation is a core area in the financial services sector because it will be contributing to the stability and growth of the financial sector and in turn leads to economic growth. Frame and White (as cited in Arnaboldi \& Rossignoli, 2009) define financial innovation as product and organizational innovation which allows cost or risk reduction for the single bank or an improvement of the services for the financial system as a whole. Financial innovation includes process, product and institutional innovation. Process innovation refers to new ways of operating business and implementing information technology, such as the Automated Teller Machine (ATM), mobile banking, point of sale terminal (POS) and online banking (Abor, as cited in Tahir et al., 2018). Product innovation consists of evolving new or modifying products, say financial instruments of securities, that are capable of attracting new customers, and serving the financial services needs of clients better. The institutional innovation refers to creation of new institutions or updating the activities of existing institutions so as to achieve improved performance of the sector, say financial system/sector.

Banks are positioned at the core of the financial sector. They are becoming both more strategically focused and technologically advanced to respond to consumer expectations while trying to defend market share against an increasing array of competitors. Banks keep developing and finding new ways of satisfying their teeming customers, beating competition, making profit, and remaining in business, among other reasons. A great deal of emphasis is being placed on digitizing core business processes and reassessing organizational structures and internal talent to be better prepared for the future of banking. This transformation illustrates the increasing desire to become a "digital bank". Even the previously called "old generation banks" are innovating new and improved ways of doing business. For instance, Union Bank Plc, one of the old generation banks in Nigeria, has adopted a slogan "simpler and smarter bank". The importance of innovation and developing new solutions that take advantage of data, advanced analytics, digital technologies and new delivery platforms cannot be over emphasized. We are seeing banks innovate in targeting, expanding services, re-configuring delivery channels, delivering proactive advice, integrating payments and applying block-chain technology. 
These efforts in innovation will surely be on continued improvement as global financial and technological giants revolutionize the financial services arena, banks being in the center stage. It is imperative in the modern era that with the high cost and attendant problems cum inconveniences of running a traditional branch network, the banks are moving their transactions to digital channels, which is the outcome of financial innovations. Just like the banks, the other financial firms are not left out in striving to use digital platforms to provide lending, investing and specialty services.

The impact of the financial innovation, say internet economy and digitalization in the banking industry, is seen in the increased move to retail banking and use of e-banking channels, which has further led to improvements in financial inclusion. According to the Central Bank of Nigeria (as cited in Nurudeen, 2018), the total value of electronic payment (e-payment) transactions recorded in 2017 rose to $\$ 83.1$ trillion in 2017 from $\$ 62.7$ trillion recorded in 2016. As digital transformations continue to shape the way banks do business, technology moves at a breakneck speed, and the numerous trends will continue to emerge and facilitate disruptions within the banking sector.

Banks especially the commercial banks are bedeviled with high risks in their operations, which extend to possible mismatch between their deposits and lending (liabilities and assets). They also face the problem of striking a balance between the liquidity and profitability quest or target set. While banks need to be liquid enough to meet their customers' demands for funds, they also must be profitable to meet expectations of shareholders, despite the prevalent innovations in use and in the face of fierce competition amongst them. Keying into financial innovations in banking such as the automated teller machine, internet banking, point of sale, cards, mobile banking, pocketmoni, amongst others are inevitable for any bank that wants to be continually in tune with realities. Banks seem to remain in stiff competition to have a significant market share of the available idle funds in the Nigerian economy, hence the need to innovate so as to woo or entice customers to them.

The broad objective of this study is to determine the relationship between financial innovation and commercial banks deposit mobilisation in Nigeria. The specific objectives are to examine the relationship between value of ATM transactions and commercial banks deposit in Nigeria, evaluate the relationship between value of internet banking transactions and commercial banks deposit in Nigeria, assess the relationship between value of mobile banking transactions and commercial banks deposit in Nigeria, and evaluate the relationship between value of POS transactions and commercial banks deposit in Nigeria.

The null hypothesis is as follows: there is no positive and significant relationship between financial innovation (value of Automated Teller Machine, internet banking, mobile banking, point of sale transactions) and financial intermediation (commercial banks deposit mobilization) in Nigeria.

The subsequent sections of this work include conceptual review, theoretical framework and empirical review of related works. Others are methodology and data presentation, discussions, summary of findings, conclusion and recommendations. 


\section{CONCEPTUAL REVIEW}

\section{Financial Innovation}

Financial innovation involves making and promoting new financial products and services, developing new processes to facilitate financial activities, to interact with customers and to design new structures for financial institutions. Abel (2018) defines financial innovation as the act of creating and then popularizing new financial instruments. This implies advances over time in the financial instruments and payment systems used in the lending and borrowing of funds as well as innovations in the payment mechanisms and systems in the economy.

Financial innovation involves the design, the development, and the implementation of innovative financial instruments and processes, and the formulation of creative solutions to problems in finance. The concept of financial innovation can be seen in a broad term as "... the act of creating and then popularizing new financial instruments as well as new financial technology, institutions and markets" (Chipeta \& Muthinja, 2018). They argued that innovation can be categorized into process and product innovations, where product innovations are denoted by new financial instruments, while process innovations are epitomized by innovative methods of distributing the financial products, dispensing transactions or pricing them.

The focus of financial innovation is to achieve innovative customer experiences (services) and increased value to their customers. The success of any innovation depends on three things. The first is how good the product is, to begin with. Some financial products are poorly conceived or designed. Next is the appropriate use of the product: Is the product meant for a particular market or type of risk? And finally, the value of an innovation hinges on the competence of the person implementing it (Abel, 2018).

The financial innovation focus in this study is the e-money products in Nigeria financial system namely automated teller machine (ATM) transactions, web transactions (internet banking), point of sale $(\mathrm{PoS})$ transactions, and mobile payments. Automated teller machine is a machine designed for the self-processing of bank transactions on behalf of the bank. ATMs are designed for not only cash withdrawals and deposits but also for other transactions such as payment of bills, airtime recharge, intra and inter-bank transfers, account balance and mini-statement enquiries. Internet banking transactions are done by banks or their customers on the internet (web). Such transactions are mainly fund transfers, bills payment and other online purchases. These transactions are done on the bank's website or links provided by the bank. The point of sale is a machine that enables product sellers and service providers to obtain online payment from their customers using their debit cards. Mobile banking transactions are transactions done by bank customers using their mobile phones. These phones may or may not be internet enabled but can be used to process funds transfers, bills payments, balances and mini-statement enquiries.

The traditional approach to technological innovations introduced by Schumpeter distinguished the following groups of innovations: (1) new products (2) new methods of production (3) opening new markets (4) new sources of supply of raw materials (5) new organization forms and business structures and (6) new methods of management (Dabic et al., as cited in Blach, 2011). 
Other popular approaches to the financial innovations concept are (1) the product innovations (2) the process innovations (3) the risk-shifting innovations (Llewellyn, as cited in Blach, 2011).

\section{Financial Intermediation}

Financial intermediation is the process whereby financial service providers like banks pull funds from the public as deposits and transform them into loanable funds (Agbada \& Osuji, 2013; Dunami, Ekokemi, Johnny \& Krokeme, 2017). It consists of the flow of funds from lenders to borrowers, from those that have to those that do not have, from those that are looking for where to put their funds to those that want to take funds. However, the movement of these funds from one end to another has to be facilitated by or go through an intermediary, hence the term "intermediation".

Financial intermediation is achieved via financial intermediaries (i.e., institutions in the intermediation process). In Nigeria basically, the banks, Nigeria stock exchange, insurance companies, reinsurance companies, pension fund managers, stockbrokers, among others act as intermediaries in the financial sector.

Financial intermediation involves the transformation of mobilized deposits liabilities by financial intermediaries such as banks into bank assets or credits such as loan and overdraft. It is simply the process whereby financial intermediaries take in money from depositors and lend the same out to borrowers for investment and other economic development purposes (Agbada \& Osuji, 2013).

According to Acha (as cited in Nwite, 2014), financial intermediation is a system of channeling funds from lenders (economic surplus unit) to borrowers (economic deficit unit) through financial institutions. The intermediation process involves moving funds from surplus economic units of the economy to deficit economic units (Uremadu, as cited in Orji, 2012). In general, banks assume an intermediary role between the ones who want to let others use money and the ones who need money.

\section{Theoretical Framework}

This study is anchored on the financial innovation theory propounded by Joseph Schumpter. Schumpeter's financial innovation theory argued that technology creates opportunities for new profits and super profits as a result of increased investment by banks or financial institutions on products of innovation (Ibenta \& Anyanwu, 2017). Joseph Alois Schumpeter, in 1912, in "The theory of Economic Development" noted that economic development is spurred by innovation within financial intermediaries (Mishra, 2008). Schumpeter (1912) indicated that innovation can take place in the form of a new product, process, market, raw material, a method of distribution, or organizational structure. This theory suits this study since this study is looking at the relationship between technologically driven innovations in the banking system and bank deposit mobilization in Nigeria.

\section{Empirical Review of Related Works}

Tahir et al. (2018) examined the impact of financial innovation products of payment used in Pakistan on the efficiency ratio (ER) of deposit money banks in the country. ER is a measure of aggregate overhead costs against operating income. The authors used ER to proxy 
performance, while volume of transactions on web/internet, ATM, POS and mobile banking were used to proxy financial innovation. Data for the variables used were obtained from the State Bank of Pakistan for the period 2007-2016. The tools for analysis were unit root test, multiple regression models and granger causality test. They found out that web/internet transactions showed a significant positive relationship, but the other three variables were statistically non-significant. The granger impact appraisal revealed that no innovative product had a critical effect on ER, but they did have a significant effect on the value of transactions.

Tahir et al., (2018) further asserted that the role of financial innovation products, namely ATMs, the Web/Internet, POS, and mobile banking in Pakistan, and their impact on the financial performance of money deposit banks, is quite irrefutable, in spite of the consistently floating fraudulent risk associated with e-payment platforms in Pakistan. After the banking consolidation reforms in Pakistan in 2004-2005, the financial activities of the deposit money banks in the country quickly increased as they tried, with their foreign competitors, to attain a competitive advantage through the utilization of advanced technologies. There is no doubt that financial innovations will keep evolving new and better products/services/processes/ways that will positively continue to impact on and help achieve efficient financial intermediation. The prime focus of financial innovation is to make financial intermediation processes (deposit mobilization and lending) effective and efficient. Financial innovations have led to the introduction of automated teller machines (ATM), point of sale (POS), internet banking, mobile banking, agency banking, RTGS (real time gross settlements), credit and debit cards, cheque clearing through automated clearing system, and SMS banking, among others.

Tahir et al. (2018) in their study explained that Pakistan initiated electronic payment system in the 2000s, and it has in the last decade witnessed increased use of electronic payments as the growth rate has increased from 19.7 percent to 44.6 percent during the period 2006-2012, while in the same period, paper-based transactions fell from 80 percent to 55 percent. The various products of financial innovation employed by banks as a strategic tool to compete have made deposit money banks improve their financial performance by simultaneously being able to enhance and maintain their efficiency and effectiveness in the market (Kamau \& Oluoch, as cited in Tahir et al., 2018).

Chipeta and Muthinja (2018) examined the relationship between financial innovations and bank performance in Kenya: evidence from branchless banking models. The study examined the relationship between financial innovation and financial performance of 42 commercial banks in Kenya. The problem of the study was that most of the studies in previous years, largely carried out in the developed world, have not kept pace with new financial innovations in developing countries. Also, the dearth of research data on emerging financial innovations could partly be explained by the fact that the innovations, such as mobile money and agency banking, are not common in developed countries. Financial innovation independent variables covered were mobile banking, agency banking, internet banking and ATM, while the dependent variables were industry adjusted Return on Asset and Return on Equity. They used the Koyck dynamic distributed lag model to estimate the relationship between financial innovation and bank financial performance. The model has been using dynamic panel estimation with a system generalized method of moments. The results showed that financial innovations significantly contribute to bank performances, and that firm specific factors are more important in determining the firm's current financial performance than industry factors. 
Ibenta and Anyanwu (2017) sought to find out the relationship between financial innovation and bank efficiency, as well as the impact of financial innovation on efficiency ratio of deposit money banks in Nigeria for the period 2006 to 2014. They obtained secondary data covering the period of the study from the Central Bank of Nigeria statistical bulletin. Unit root test was performed to ensure that the variables were free from stationarity defect, while multiple regression model was developed and estimated to evaluate the relationship among the variables used. Their findings revealed that the value of transactions on Automated Teller Machine (ATM) and Point of Sale (POS) are negatively related with efficiency ratio while web/internet and mobile banking are positively related, but only that of web/internet was significantly related. The granger impact assessment depicted that financial innovation products reflected by value of transaction on ATMs, web/internet, POS and mobile banking has no significant impact on efficiency ratio of deposit money banks in Nigeria. The authors found out that banks efficiency ratio exerted a statistically significant impact on the value of transactions on ATMs.

Kashmari, Nejad and Nayebyazdi (2016) examined the influence of financial innovation on the share of each bank in attaining deposits. Secondary data were collected from twenty-three banks from the period 2007-2013. The Panel Data-Vector Autoregressive method (PanelVAR) and Granger Causality Test were applied to the data. The study concluded that the SWIFT system, Point of Sale terminal, mobile banking, ATM machines, personal identification number (PIN), and other banking facilities provided by each bank showed that a causal relation in improving the share was caused by innovation. A bilateral relation among the share of deposits and facilities provided by the bank was also found.

Kamau and Oluoch (2016) examined the impact of internet banking, debit cards, credit cards, agency banking, mobile banking and ATMs on the financial performance of banks in Kenya. Secondary data were collected from the annually published financial statements of the banks. Eleven commercial banks were selected using correlation research design to assess the causal impact of financial innovations on the banks' performance from 2012-2015. The descriptive analysis done showed that average bank performance was $23.7 \%$. Correlation analysis revealed that banks' financial performance was greatly influenced by ATM banking. The study concluded in aggregate on the basis of regression analysis that ATMs, debit and credit cards, mobile banking, web banking and agency banking all have a strong influence on commercial banks' performance.

Gichungu and Oloko (2015) investigated the relationship between bank innovations and financial performance of commercial banks in Kenya. The proxies for bank innovations were ATMs, web banking, agency banking and mobile banking. The data were collected from fortythree commercial banks annually published reports for the time period 2009-2013. They used the time span of 2009-2013 because of major technological innovations that were implemented by the banks during that time period. The data were analyzed using Multiple Regression, along with the Pearson Product Moment Correlation Coefficient test, to gauge the impact of financial innovations on the performance of the banks. The statistical result of the correlation coefficient test showed the direction and magnitude of the dependent and independent variables relationship and revealed that in the dependent-independent variable relationship, there is a 95\% confidence level and a 5\% level of significance. The study found out that there was a strong positive impact of financial innovation on the financial performance of banks during the period 2009-2013 in the banking sector in Kenya. 
Ilo, Wilson and Nnanyelugo (2014) investigated the impact of technological innovation on the delivery of banking services. Qualitative data were collected through questionnaires of which 436 were returned from respondents out of 1,250 given out. The study covered the period 20082013. Pearson Correlation statistics was used to analyse the data. The results revealed that there is a positive connection between financial innovation and banks' performance.

Mwinzi (2014) in his research in Kenya examined empirically the effect of financial innovations on economic growth in Kenya. Financial innovation was proxied by mobile money payment systems, mobile banking and RTGS, while the dependent variable which is economic growth was proxied by gross domestic product. The study used secondary data obtained from the Central Bank of Kenya, Kenya Bureau of Statistics and other institutions. They analysed the data using a regression method with the help of SPSS. The study found out that financial innovation has an insignificant positive impact on economic growth, and also that RTGS innovations and mobile banking have insignificant effects on financial deepening in Kenya. They concluded that the rise in mobile money transactions as well as in m-banking in Kenya have significantly influenced economic growth.

Malak (2014) examined the impact of financial innovation on banks' financial performance as the major players in the sector over a period of five years. Sixteen registered commercial banks with the Central Bank of South Sudan were selected. Data was for the period 2009-2013 and a causal research design was used to collect data. The study concluded that financial innovation products significantly influenced the financial performance of commercial banks operating in South Sudan.

Ongore and Kusa (2013) assessed the interconnection between technological advancements and the financial performance of the banking sector. The data were collected from published reports of banks registered with the Central Bank. Data were collected from forty-four commercial banks and regression analysis was conducted to gauge the relationship between the study's interest variables. The independent variables were ATM, mobile banking, web banking and the dependent variable was profit. The findings of the study revealed that ATM machines offer more than just acting as cash dispensers and are transformed as a tool of superior customer relationship management, eventually creating long-term customer value and loyalty. Mobile banking is one of those factors that directly influence the profitability of the banks, as operations become smoother, and web banking provides the convenience of conducting most of the banking operations at a time and place (office, home, etc.) that best suits the customers. A credit card provides the banks with a greater opportunity to improve income and diminishes the credit and liquidity risk of operations.

Gakure and Ngumi (2013) used descriptive research design to measure the profitability of commercial banks in relation to financial innovations. They applied multiple linear regression analysis to gauge the statistical significance of these independent variables (automated teller machines, point of sale terminals, debit and credit cards, e-banking, mobile banking, and efunds transfer) on the dependent variable profit before tax. The independent variable financial innovation was measured based on the Likert scale. The study demonstrated that the financial performance of banks was moderately influenced by financial innovation products.

Blach (2011) examined the financial innovations and their role in the modern financial systemidentification and systematization of the problem. He discussed the role of financial innovations in the modern financial system. A theoretical review of the definitions, importance, 
origin, history and classifications of financial innovation was done. Various research works related to the topic were reviewed leading to identification and systematization of the problem. He concluded by stating that sustainable financial innovations are required as they enhance the efficiency of the financial system, and by this they can improve economic growth and increase social wealth. The efficient usage of a particular financial innovation requires an extensive knowledge about its way of functioning and a thorough analysis of its consequences. He recommended further theoretical and empirical research on the topic.

Deyoung, Land and Nolle (2007) study of 424 community banks, comprising the earliest adopters of internet banking in the USA, explains the implication of financial innovation adoption. The study compared the change in the banks' 1999-2001 financial performance with that of 5,175 community banks using branch-only banking. They found an improvement in the profitability of the early adopters of internet banking among community banks associated with internet banking.

Caineli, Evangelista and Savona (2006) assessed the impacts of innovation on the service firms' economic performance by both conceptually and empirically exploring the birelationship between innovation and firm-level economic performance and reporting several important findings. Firstly, the study finds a strong positive relationship between innovation and a firm's economic performance. Secondly, innovating firms perform better than noninnovating firms in terms of economic growth and productivity. Thirdly, a reverse or circular relationship between innovation and firm performance is evidenced by the higher propensity for better performing firms to innovate and commit their capital to innovation.

The reviewed studies underlined the effect of financial innovation on commercial banks performance. Some of these innovations were seen to contribute in different ways to financial intermediation. Some studies on the impact of financial intermediation on economic growth were also reviewed, and they showed that financial intermediation positively impacts on economic growth. So as financial innovations impact on financial intermediation, it in turn impacts on economic growth. Financial innovation variables covered in the various empirical studies include automated teller machine, internet banking, point of sale, mobile banking, debit and credit cards, agency banking, and SWIFT system.

\section{METHODOLOGY}

The research design of this study is ex-post facto design. Multiple regression analysis was used. This relationship can be expressed as

$Y_{t}=b_{o}+b_{1} x_{1}+b_{2} X_{2}+b_{3} X_{3}+\ldots \ldots \ldots . B_{t} X_{t}+e_{t}$

where:

$\mathrm{Y}=$ dependent variable

$b_{o}=$ intercept

$\mathrm{x}_{1}, \mathrm{x}_{2}, \mathrm{x}_{3}$ are the independent variables

$e_{t}=$ random error term 
African Journal of Accounting and Financial Research

ISSN: 2682-6690

Volume 4, Issue 3, 2021 (pp. 162-179)

www.abjournals.org

$b_{0}, b_{1}, b_{2}, b_{3}$ are the parameters of the model.

This study adapted the model in the study by Tahir et al., (2018) which used the function:

$\mathrm{EFR}_{\mathrm{t}}=\mathrm{f}(\mathrm{VATM}, \mathrm{VWEB}, \mathrm{VMOB}, \mathrm{VPOS})$

where: $\mathrm{EFR}=$ efficiency ratio; VATM = value of ATM transactions; VWEB = value of WEB transactions; VPOS = value of POS transactions.

This study used the model:

$\mathrm{CBD}=\mathrm{f}(\mathrm{ATM}, \mathrm{IB}, \mathrm{MB}, \mathrm{POS})$

The model is functionally expressed as follows:

$\mathrm{CBD}=\mathrm{b}_{\mathrm{o}}+\mathrm{b}_{1} \mathrm{ATM}+\mathrm{b}_{2} \mathrm{IB}+\mathrm{b}_{3} \mathrm{MB}+\mathrm{b}_{4} \mathrm{POS}+\mathrm{e}_{\mathrm{t}}(2)$

where:

$\mathrm{CBD}=$ Commercial banks deposit

$\mathrm{ATM}=$ Automated teller machine

$\mathrm{IB}=$ Internet banking

MB = Mobile banking

POS $=$ Point of sale

\section{A priori Expectation:}

The a priori expectation is that increase in the value of the independent variables should lead to increase in the dependent variable.

\section{Data Presentation}

The data processed are depicted in Table 1, the descriptive statistics are depicted in Table 2, and Table 3 shows the coefficient of correlations among the input variables. The regression out data showing the parameter estimates are displayed in Table 4.

Table 1: Data on commercial banks deposit, automated teller machine, internet banking, mobile banking and point of sale

\begin{tabular}{|l|l|l|l|l|l|}
\hline Year & $\begin{array}{l}\text { Commercial } \\
\text { bank deposits } \\
\text { (CBD) 'Billion }\end{array}$ & $\begin{array}{l}\text { Automated } \\
\text { Teller Machine } \\
\text { (ATM) Billion }\end{array}$ & $\begin{array}{l}\text { Internet } \\
\text { Banking (IB) } \\
\text { N'Billion }\end{array}$ & $\begin{array}{l}\text { Mobile } \\
\text { Banking (MB) } \\
\text { 'Billion }\end{array}$ & $\begin{array}{l}\text { Point of } \\
\text { Sale (POS) } \\
\text { A'Billion }\end{array}$ \\
\hline 2009 & $9,150.04$ & 548.6 & 84.15 & 1.27 & 11.03 \\
\hline 2010 & $9,784.54$ & 339.71 & 25.05 & 6.65 & 12.72 \\
\hline 2011 & $11,452.76$ & $1,561.74$ & 59.61 & 18.98 & 31.02 \\
\hline 2012 & $13,132.09$ & $1,984.65$ & 31.56 & 31.51 & 48.01 \\
\hline 2013 & $13,767.46$ & $2,828.93$ & 47.3 & 142.8 & 161.01 \\
\hline 2014 & $17,185.80$ & $3,679.88$ & 74.05 & 346.48 & 312.05 \\
\hline 2015 & $17,276.67$ & $3,970.25$ & 91.58 & 442.37 & 448.5 \\
\hline
\end{tabular}


African Journal of Accounting and Financial Research

ISSN: 2682-6690

Volume 4, Issue 3, 2021 (pp. 162-179)

www.abjournals.org

\begin{tabular}{|l|l|l|l|l|l|}
\hline 2016 & $18,326.95$ & $4,988.13$ & 132.35 & 756.89 & 758.99 \\
\hline 2017 & $19,146.81$ & $6,437.58$ & 184.6 & $1,101.99$ & $1,409.81$ \\
\hline 2018 & $21,430.85$ & $6,480.45$ & 546.72 & $1,830.26$ & $2,383.29$ \\
\hline
\end{tabular}

Source: Central Bank of Nigeria Statistical bulletin and website (financials)

Table 2: Descriptive statistics of the input variables

$\begin{array}{lccccc} & \text { CBD } & \text { ATM } & \text { IB } & \text { MB } & \text { POS } \\ \text { Mean } & 15065.40 & 3281.992 & 127.6970 & 467.9200 & 557.6430 \\ \text { Median } & 15476.63 & 3254.405 & 79.10000 & 244.6400 & 236.5300 \\ \text { Maximum } & 21430.85 & 6480.450 & 546.7200 & 1830.260 & 2383.290 \\ \text { Minimum } & 9150.040 & 339.7100 & 25.05000 & 1.270000 & 11.03000 \\ \text { Std. Dev. } & 4197.259 & 2228.773 & 154.8465 & 604.1666 & 779.0340 \\ \text { Skewness } & -0.047308 & 0.171775 & 2.229201 & 1.273538 & 1.493722 \\ \text { Kurtosis } & 1.696890 & 1.775818 & 6.680983 & 3.515686 & 4.018288 \\ & & & & & \\ \text { Jarque-Bera } & 0.711270 & 0.673604 & 13.92791 & 2.813972 & 4.150722 \\ \text { Probability } & 0.700728 & 0.714050 & 0.000945 & 0.244880 & 0.125511 \\ & & & & & \\ \text { Sum } & 150654.0 & 32819.92 & 1276.970 & 4679.200 & 5576.430 \\ \text { Sum Sq. Dev. } & 1.59 \mathrm{E}+08 & 44706874 & 215796.9 & 3285155 . & 5462046 . \\ & & & & & \\ \text { Observations } & 10 & 10 & 10 & 10 & 10\end{array}$

Source: E-view version 8 output data on input variables

Tables 1 and 2 show that volume and value of payments on different channels (say ATM, IB, $\mathrm{MB}$, and POS) were steadily rising. CBD value has also continued to increase. It can be said that the payment system has stimulated economic activities in Nigeria in increasing measures. Whether the commercial banks' role in intermediation given the financial innovation (e-money payment channels) has been significant is a question to answer.

Table 3: Coefficient of correlations among the input variables

$\begin{array}{cccccc} & \text { CBD } & \text { ATM } & \text { IB } & \text { MB } & \text { POS } \\ \text { CBD } & 1 & 0.97 & 0.69 & 0.87 & 0.83 \\ \text { ATM } & 0.97 & 1 & 0.70 & 0.89 & 0.86 \\ \text { IB } & 0.69 & 0.70 & 1 & 0.92 & 0.94 \\ \text { MB } & 0.87 & 0.89 & 0.92 & 1 & 0.99 \\ \text { POS } & 0.83 & 0.86 & 0.94 & 0.99 & 1\end{array}$

Source: E-view version 8 output data on input variables 
Table 3 shows that the coefficient of correlation between financial innovation and financial intermediation is high. CBD and ATM was 0.97, CBD and IB was 0.69, CBD and MB was 0.87 , and CBD and POS was 0.83 .

Table 4: Regression output parameters of input variables against CBD

\begin{tabular}{crrrr}
\hline Variable & Coefficient & Std. Error & t-Statistic & Prob. \\
\hline ATM & 1.989731 & 0.569817 & 3.491879 & 0.0174 \\
IB & 11.71177 & 9.517656 & 1.230530 & 0.2732 \\
MB & 7.831350 & 7.260256 & 1.078660 & 0.3300 \\
POS & -8.690776 & 4.748070 & -1.830381 & 0.1267 \\
C & 8221.465 & 1140.932 & 7.205922 & 0.0008
\end{tabular}

$\begin{array}{lrll}\text { R-squared } & 0.974213 & \text { Mean dependent var } & 15065.40 \\ \text { Adjusted R-squared } & 0.953583 & \text { S.D. dependent var } & 4197.259 \\ \text { S.E. of regression } & 904.2858 & \text { Akaike info criterion } & 16.75902 \\ \text { Sum squared resid } & 4088664 . & \text { Schwarz criterion } & 16.91031 \\ \text { Log likelihood } & -78.79510 & \text { Hannan-Quinn criter. } & 16.59305 \\ \text { F-statistic } & 47.22331 & \text { Durbin-Watson stat } & 2.519975 \\ \text { Prob(F-statistic) } & 0.000367 & & \\ \text { Source: } \text { E-view version 8 output data of the input data variables }\end{array}$

From Table 4, the R-squared of 0.97 and adjusted R-squared of 0.95 indicate that the independent variables (financial innovation represented by the e-money payment channels) explained 97\% (95\% in real terms) changes in the financial intermediation (commercial banks deposit). The prob (F-statistic) of 0.000367 shows that the model is fit to explain significance of the relationships. The coefficients of the relationship were positive except for POS (8.690776).

\section{Hypothesis Testing}

The study proposed that there is no positive and significant relationship between financial innovation (value of Automated Teller Machine, internet banking, mobile banking, point of sale transactions) and financial intermediation (commercial banks deposit mobilization) in Nigeria.

The decision rule: If the probability value of the independent variable is less than 0.05 , the null hypothesis is rejected and the alternate hypothesis accepted. On the other hand, if the probability value of the independent variable is greater than 0.05 , the null hypothesis is accepted and the alternate hypothesis rejected. 


\section{Table 5: Summary statistics for hypothesis testing}

$\begin{array}{ccrrrrr}\text { Hypothesis } & \text { Variable } & \text { Coefficient } & \text { Std Error } & \text { t-Statistic } & \text { Prob } & \text { Decision } \\ \text { One } & \text { ATM } & 1.989731 & 0.569817 & 3.491879 & 0.0174 & \text { Reject Ho } \\ \text { Two } & \text { IB } & 11.71177 & 9.517656 & 1.230530 & 0.2732 & \text { Accept Ho } \\ \text { Three } & \text { MB } & 7.831350 & 7.260256 & 1.078660 & 0.3300 & \text { Accept Ho } \\ \text { Four } & \text { POS } & -8.690776 & 4.748070 & -1.830381 & 0.1267 & \text { Accept Ho }\end{array}$

Source: Extracts from Table 4

We conclude as follows:

1. Given the coefficient value of 1.989731 and p-value 0.0174 , we reject the null hypothesis and accept the alternate one. Thus, there is a positive and significant relationship between financial innovation (value of Automated Teller Machine) and financial intermediation (commercial banks deposit mobilization) in Nigeria.

2. Given the coefficient value of 11.71177 and p-value 0.2732 , we will not reject the null hypothesis. Thus, there is a positive but no significant relationship between financial innovation (internet banking) and financial intermediation (commercial banks deposit mobilization) in Nigeria.

3. Given the coefficient value of 7.831350 and p-value 0.3300 , we will not reject the null hypothesis. Thus, there is a positive but no significant relationship between financial innovation (mobile banking) and financial intermediation (commercial banks deposit mobilization) in Nigeria.

4. Given the coefficient value of -8.690776 and p-value 0.1267 , we will not reject the null hypothesis. Thus, there is no positive and significant relationship between financial innovation (point of sale transactions) and financial intermediation (commercial banks deposit mobilization) in Nigeria.

Generally, the result output revealed the F-statistic to be 47.22331 and Prob (F-statistic) is 0.000367 at $5 \%$ level of significance. This denotes that financial innovation is statistically significant in explaining the changes in commercial banks deposit. We therefore reject the null hypothesis $\left(\mathrm{H}_{0}\right)$ and accept the alternate hypothesis $\left(\mathrm{H}_{\mathrm{a}}\right)$, and conclude that there is significant relationship between financial innovation (value of Automated Teller Machine, internet banking, mobile banking, point of sale transactions) and financial intermediation (commercial banks deposit mobilization) in Nigeria.

\section{DISCUSSION OF FINDINGS}

There is a positive and significant relationship between financial innovation (value of Automated Teller Machine) and financial intermediation (commercial banks deposit mobilization) in Nigeria. The result is expected. From the data extracted, it can be seen also that the value of the e-money channels rose by $15 \%$ to 10 (503.8 billion naira), compared with 9 (134.0 billion) in 2017. The volume must have also increased reasonably. In fact, the ATM is the dominant financial innovation, no wonder the findings. By inferences, whatever could 
impinge on the confidence of the users of ATM must be avoided if the benefits must be maximized. There are cases of security breaches and power outages, and regular cases of malfunctioning machines and shortage of funds.

There is a positive but no significant relationship between financial innovation (internet banking) and financial intermediation (commercial banks deposit mobilization) in Nigeria. There is a positive relationship as expected, but the no significant instance may be attributed to lag in acceptability of internet banking. Of course, there is an improving level of acceptability as indicated by increasing the value of transactions. For instance, in 2017, the value was 184.6 billion naira, compared with 546.7 billion in 2018 . The speed of acceptability should be a concern for actions. It is pertinent that those things that shall guarantee security, improve trust, ease and make for lowering transaction cost and time should be focused.

There is a positive but no significant relationship between financial innovation (mobile banking) and financial intermediation (commercial banks deposit mobilization) in Nigeria. This finding is remarkable. The value of mobile payment has also maintained an increasing trend. For instance, in 2017, the value was 1,102 billion naira, but in 2018, the value of mobile payments stood at 1,236.1 billion naira (which is about $12.2 \%$ growth rate). Statistically, the growth rate was judged non-significant. This may not also be unconnected to sluggish increasing awareness and trust in mobile banking by prospective users.

The study also discovered that there is no positive and significant relationship between financial innovation (point of sale transactions) and financial intermediation (commercial banks deposit mobilization) in Nigeria. This is worrisome. This presupposed that insecurity and lack of confidence on the channel by the users were evident during the period of the study. The study expected a positive relationship. The value of POS terminal payments prior to 2017 was rising at an abysmal rate. Between 2017 and 2018, the growth rate was 69\% (1,409.8 billion naira to $2,383.3$ billion naira). The agency banking programme introduced by the CBN might have stimulated the growth. Assuming that the growth rate is sustained from 2019 upwards, many users might become financially included; thus, the relationship will likely be positive and significant.

The financial sector environment is becoming globalized. The competition is rising and margins are getting thin for institutions that lag in financial innovations. The regulation of the sector is also characterized by dynamism and regular reforms to remain in charge given steady innovations in the system.

There is no gainsaying that financial institutions must place innovation as a top priority. This is because consumer needs will continue to be associated with ease, self-pleasure, prompt delivery, one-stop shop, and reduced cost. Increased commitment to innovation in response to consumer expectations and increased fear of non-traditional players are two of the primary things that banks must key into so as to enhance their financial intermediation progress in Nigeria. The banks must keep on finding new and better products and services not only to attract customers but also to keep them. The banks should seek easier and smarter ways of getting funds (attracting deposits), and of course promoting as well as packaging customer oriented credit facilities. 


\section{SUMMARY OF FINDINGS}

The summary of findings of this study is as follows:

1. There is a positive and significant relationship between financial innovation (value of Automated Teller Machine) and financial intermediation (commercial banks deposit mobilization) in Nigeria.

2. There is a positive but no significant relationship between financial innovation (internet banking) and financial intermediation (commercial banks deposit mobilization) in Nigeria.

3. There is a positive but no significant relationship between financial innovation (mobile banking) and financial intermediation (commercial banks deposit mobilization) in Nigeria.

4. There is no positive and significant relationship between financial innovation (point of sale transactions) and financial intermediation (commercial banks deposit mobilization) in Nigeria.

\section{CONCLUSION}

Generally, there is a significant relationship between financial innovation (value of Automated Teller Machine, internet banking, mobile banking, point of sale transactions) and financial intermediation (commercial banks deposit mobilization) in Nigeria. Some financial innovations variables have been shown by this research work to contribute to commercial banks' deposit in Nigeria. Awareness and confidence in the financial innovations by the users are factors that will make for improved financial intermediation by the banks in Nigeria. Thus, the development of the financial innovations in Nigeria should not be compromised since they contribute to growing commercial banks' deposits in Nigeria.

\section{RECOMMENDATIONS}

Following the findings made, this study recommends the following to leverage on confidence of users on the e-money payment channels:

1. The banks should increase the security on their innovative products such as the use of passwords or token to authorize transactions in addition to the 4-digit pin generally in use, as some customers do not use them due to the risk of loss of funds or falling prey to hackers.

2. Banks should improve on their technological infrastructure by continually updating these innovative products to operate with the latest upgrades and versions available, so as to make their customers' use of these innovative products easier and friendly.

3. Banks should improve on the use of standby generators to power their ATMs and other emoney payment channels to avoid any downtime due to power outage. The use of renewable energy should also be factored in the technology of the financial innovations. 
4. Banks must promptly pay for network connectivity to the providers (telecommunication companies) and also ensure that the staff concerned are properly trained, remunerated and empowered to remain on duty $24 / 7$ to avoid or promptly fix any network challenge as regards these innovative products, so that there can be increased use of these service platforms.

5. Banks should work towards customization of the financial innovations deployed for customers use, say by downloading apps on their devices for peculiar services needed. This can be enhanced by allowing the customer to use pin, password and token or use pin and token as they want for their transaction authorization, rather than compelling all customers to use the same authorization processes.

6. Banks should address the inefficiency of some bank staff in the areas of delayed response to resolving customers' complaints by availing them to psychological and communication training to enhance their productivity. The banks should therefore routinely subject the staff to upgrading courses and training with emerging developments in the global financial system.

7. And, to leverage on awareness creation:

a. Banks should continue to update the customers on innovations and security tips through the internet, social media, circulation of information fliers, and short messages to their phones.

b. Banks should ensure orderly recruitment, registration and training of agent banking personnel. The efficient performance of the agents will not only improve awareness of the banks' products, but also promote financial inclusion and growing bank deposits.

\section{REFERENCES}

Abel, S. (2018). Advantages and disadvantages of financial innovation. Bankers Association of Zimbabwe. Retrieved from http://baz.org.zw.

Agbada, O. A., \& Osuji, C. C. (2013). An Empirical analysis of trends in financial intermediation and output in Nigeria. Global Journals Inc. (USA), 13(9), 210-216.

Arnaboldi, K. \& Rossignoli, H. (2018). Financial innovation in banking. Journal of Bank Risk, Governance and Regulation, 127-162.

Blach, J. (2011). Financial innovations and their role in the modern financial system identification and systematization of the problem. Financial Internet Quarterly, $e$ finanse, 7(3). Retrieved from https://www.e-finanse.com.

Cainelli, G., Evangelista, R., \& Savona, M. (2006). Innovation and economic performance in services: A firm-level analysis. Cambridge Journal of Economics, 30(3), 435-458. Retrieved from https://doi.org/10.1093/cje/bei067.

Chipeta, C., \& Muthinja, M. M. (2018). Financial innovation and bank performance in Kenya: Evidence from branchless banking models. South African Journal of Economics and Management Sciences, 21(1), ISSN (online) 2222-3436.

Deyoung, R., Lang, W. W., \& Nolle, D. L. (2007). How the internet affects output and performance at community banks. Journal of Banking \& Finance, 31(4), 1033-1060. Retrieved from https://doi.org/10.1016/j.jbankfin.2006.10.003. 
Dumani, M., Ekokemi, T. T., Johnny, N., \& Krokeme, O. (2017). Impact of financial intermediation on economic growth in Nigeria: A disaggregate approach. Journal of Economics and Sustainable Development, 8(22).

Gakure, R., \& Ngumi, P. (2013). Do bank innovations influence profitability of commercial banks in Kenya? Prime Journal of Social Science, 2(3), 237-248.

Gichungu, Z. N., \& Oloko, M. A. (2015). Relationship between bank innovations and financial performance of commercial banks in Kenya. International Journal of Education and Research, 3(5), 443-456.

Ibenta, S. N., \& Anyanwu, F. A. (2017). Financial innovation and efficiency on the banking sub- $\quad$ sector: The case of deposit money banks and selected instruments of electronic banking (2006-2014). Asian Journal of Economics, Business and Accounting, 2(1), 112.

Ilo, J. V., Wilson, A., \& Nnanyelugo, S. (2014). Impact of technological innovation on delivery of banking services in Nigeria. 14th International Conference on Economics, Education and Humanities, Indonesia, January, 162-168.

Kamau, D. M., \& Oluoch, J. (2016). Relationship between financial innovation and commercial bank performance in Kenya. International Journal of Social Sciences and Information Technology, 2(4), 34-47.

Kashmari, A., Nejad, A. H. G., \& Nayebyazdi, A. (2016). Impact of electronic banking innovations on bank deposit market share. The Journal of Internet Banking and Commerce, 21(1), 1-12.

Malak, M. P. (2014). The effects of financial innovation on the financial performance of commercial banks in South Sudan (doctoral thesis), University of Nairobi, Kenya. Retrieved from http://erepo.usiu.ac.ke/11732/4600.

Mishra, P. K. (2008). The theory of Economic Development. International Research Journal of Finance and Economics, 40, 86 - 97.

Mwinzi, D. M. (2014). The effect of financial innovation on economic growth in Kenya, (Master's Thesis, University of Nairobi, Kenya). Retrieved from http://hdl.handle.net/11295/74849.

Nkem, I. S., \& Akujinma, A. F. (2017). Financial innovation and efficiency on the banking sub-sector: the case of deposit money banks and selected instruments of electronic banking. Asian Journal of Economics, Business and Accounting, 2(1), 1-12.

Nurudeen, K. (2018). Trends set to impact Nigeria's banking industry. Retrieved from https://www.wikipedia.com.

Ogiriki, T., \& Andabai, P. W. (2014). Financial intermediation and economic growth in Nigeria (1988-2013): A vector error correction investigation. Mediterranean Journal of Social Sciences, 5(17). Rome-Italy: MCSER Publishing.

Ongore, V. O., \& Kusa, G. B. (2013). Determinants of financial performance of commercial banks in Kenya. International Journal of Economics and Financial Issues, 3(1), 237.

Orji, A. (2012). Bank savings and bank credits in Nigeria: Determinants and impact on economic growth. International Journal of Economics and Financial Issues, 2(3), 357372. ISSN 2146-4138.

Tahir, S. H., Shah, S., Arif, F., Ahmed, G., Aziz, Q., \& Ullah, M. R. (2018). Does financial innovation improve performance? An analysis of process innovation used in Pakistan. Journal of Innovation Economics and Management, 3(27), 195-214.

Tony, O., \& Andabai, P. W. (2014). Financial intermediation and economic growth in Nigeria, 1988-2013: A vector error correction investigation. Mediterranean Journal of Social Sciences, 5(17). 
African Journal of Accounting and Financial Research

ISSN: 2682-6690

Volume 4, Issue 3, 2021 (pp. 162-179)

www.abjournals.org

Umoh, O. J., \& Okoye, K. U. (2018). On the efficiency of financial intermediation in Nigeria's growth performance: A two stage least square approach. European Journal of Scientific Research, 95 (4), 444-456. Munich Personal RePec Archive.

Uremadu, S. O. (2007). The impact of real interest rate on savings mobilization in Nigeria. Unpublished doctoral thesis proposal, University of Nigeria, Enugu Campus. 